\title{
Introduction To Futures Markets
}

\author{
James Mintert and Mark Welch*
}

Futures trading has a long history, both in the U.S. and around the world. Futures trading on a formal futures exchange in the U.S. originated with the formation of the Chicago Board of Trade (CBOT) in the middle of the 19th Century. Grain dealers in Illinois were having trouble financing their grain inventories. The risk of grain prices falling after harvest made lenders reluctant to extend grain dealers credit to purchase grain for subsequent sale in Chicago. To reduce their risk exposure, grain dealers began selling "To Arrive" contracts, which specified the future date (usually the month) a specified quantity of grain would be delivered to a particular location at a price identified in the contract. Fixing the price in advance of delivery reduced the grain dealer's risk and made it easier to obtain credit to finance grain purchases from farmers. The "To Arrive" contracts were a forerunner of the futures contracts traded today. Although dealers found it advantageous to trade what essentially were forward cash contracts in various commodities, they soon found these forward cash contract markets inadequate and formed futures exchanges.

The first U.S. futures exchange was the Chicago Board of Trade (CBOT), formed in 1848. Other U.S. exchanges also began in the last half of the 1800s. For example, the Kansas City Board of Trade (KCBT) traces its roots to January 1876 when a precursor to today's hard red wheat futures contract was first traded. Similarly, a forerunner of the Chicago Mercantile Exchange
(CME) was formed in 1874 when the Chicago Product Exchange was organized to trade butter. In each case the exchanges were formed because commercial dealers in corn, wheat and butter needed a way to reduce some of their price risk, which hampered the day-to-day management of their businesses. Sellers wanted to rid themselves of the price risk associated with owning inventories of grain or butter and buyers wanted to establish prices for these products in advance of delivery. In recent years futures contracts have proliferated, particularly in the financial arena, as businesses become more aware of the price risks they face and seek ways to reduce them.

\section{What Is A Futures Contract?}

A futures contract is a binding agreement between a seller and a buyer to make (seller) and to take (buyer) delivery of the underlying commodity (or financial instrument) at a specified future date with agreed upon payment terms. Most futures contracts don't actually result in delivery of the underlying commodity. Instead, most traders find it advantageous to settle their futures market obligation by selling the contract (in the case of a contract that was purchased initially) or by buying it back (in the case of a contract that was sold initially). The trader then completes the actual cash transaction in his or her local cash market.

Futures contracts are standardized with respect to the delivery month; the commodity's quantity, quality, and delivery location; and the

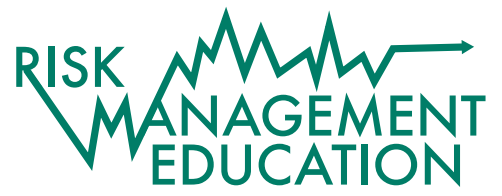

*Professor and Extension Agricultural Economist, Kansas State University Agricultural Experiment Station and Cooperative Extension Service, and Assistant Professor and Extension Economist-Grain Marketing, The Texas A\&M System. 
payment terms. The fact that the terms of futures contracts are standardized is important because it enables traders to focus their attention on one variable, price. Standardization also makes it possible for traders anywhere in the world to trade in these markets and know exactly what they are trading. This is in sharp contrast to the cash forward contract market, in which changes in specifications from one contract to another might cause price changes from one transaction to another. One reason futures markets are considered a good source of commodity price information is because price changes are attributable to changes in the commodity's price level, not changes in contract terms.

Unlike the forward cash contract market, futures exchanges provide:

- Rules of conduct that traders must follow or risk expulsion

- An organized market place with established trading hours by which traders must abide

- Standardized trading through rigid contract specifications, which ensure that the commodity being traded in every contract is virtually identical

- A focal point for the collection and dissemination of information about the commodity's supply and demand, which helps ensure all traders have equal access to information

- A mechanism for settling disputes among traders without resorting to the costly and often slow U.S. court system

- Guaranteed settlement of contractual and financial obligations via the exchange clearinghouse

\section{The Purpose of Futures Markets}

Futures markets serve two primary purposes. The first is price discovery. Futures markets provide a central market place where buyers and sellers from all over the world can interact to determine prices. The second purpose is to transfer price risk. Futures give buyers and sellers of commodities the opportunity to establish prices for future delivery. This price risk transfer process is called hedging.

\section{Changes in a Futures Contract's Value}

A futures contract's value is simply the number of units (bushels, hundredweight, etc.) in each contract times the current price. Each contract specifies the volume of grain or livestock it covers. Both Chicago and Kansas City Board of Trade grain and oilseed futures contracts cover 5,000 bushels. The CME's live cattle futures contract covers 40,000 pounds ( 400 hundredweight) of live weight steers. The lean hogs futures contract covers 40,000 pounds ( 400 hundredweight) of carcass weight pork and the feeder cattle futures contract covers 50,000 pounds ( 500 hundredweight) of feeder steers. To determine both contract value and changes in contract value, examine the July KCBT wheat futures contract on a day when the settlement price is $\$ 6.00$ per bushel. The total contract value would simply be 5,000 bushels times $\$ 6.00$ or $\$ 30,000$. If the July KCBT wheat futures price changes to $\$ 6.10$ per bushel the next day, the new contract value is 5,000 bushels times $\$ 6.10$ or $\$ 30,500$. The change in contract value is $\$ 30,500$ minus $\$ 30,000$, or $\$ 500$. Alternatively, you can compute the change in contract value by simply multiplying the price change per unit $(\$ 6.10-\$ 6.00=\$ 0.10 /$ bushel) times the number of units in the contract $(\$ 0.10 /$ bushel $x 5,000$ bushels $=\$ 500$ ).

The effect of a change in contract value depends on whether you previously sold or purchased a futures contract. A decrease in contract value (a price decline) is a loss to anyone who previously purchased a futures contract, but a gain for a trader who previously sold a futures contract. Conversely, an increase in contract value (a price increase) is a gain to anyone who previously purchased a futures contract (i.e., is long), but is a loss for a trader who previously sold a futures contract (i.e., is short). One trader's loss is another trader's gain. For example, in the previous wheat futures example, a trader who purchased July KCBT wheat futures at $\$ 6.00$ / bushel saw the value of his futures market account increase by $\$ 500$ when the price rose to \$6.10; a trader who sold a futures contract at $\$ 6.00 /$ bushel saw the value of his futures market 
account decline by $\$ 500$. The $\$ 500$ gain earned by the futures contract buyer came from the futures contract seller's \$500 loss via the exchange clearinghouse, as outlined in Figure 1.

Futures contract performance is guaranteed by the exchange through an institution known as the exchange clearinghouse, which tracks the value of each trader's position and ensures that sufficient funds are available to cover each trader's obligations. The exchange clearinghouse requires that traders (via the futures

Figure 1. Marking-to-Market Buyer and Seller Accounts at Exchange Clearinghouse.

Buyer (Long)

\begin{tabular}{|c|c|c|}
\hline Date & Action & Price \\
\hline Day 1 & Buy at & $\$ 6.00 / \mathrm{bu}$ \\
\hline \multirow[t]{3}{*}{ Day 2} & $\begin{array}{l}\text { No action (but } \\
\text { price increases) }\end{array}$ & $\$ 6.10 / \mathrm{bu}$ \\
\hline & & $\begin{array}{r}\$ 0.10 / \text { bu gain } \\
\text { x 5,000 bu }\end{array}$ \\
\hline & & $\begin{array}{l}\$ 500 \text { gain } \\
\text { from day } 1\end{array}$ \\
\hline \multicolumn{3}{|c|}{ Seller (Short) } \\
\hline Date & Action & Price \\
\hline Day 1 & Sell at & $\$ 6.00 / \mathrm{bu}$ \\
\hline \multirow[t]{3}{*}{ Day 2} & $\begin{array}{l}\text { No action (but } \\
\text { price increases) }\end{array}$ & $\$ 6.10 / \mathrm{bu}$ \\
\hline & & $\begin{array}{r}\$ 0.10 / \mathrm{bu} \text { loss } \\
\times 5,000 \mathrm{bu}\end{array}$ \\
\hline & & $\begin{array}{l}\$ 500 \text { loss } \\
\text { from day } 1\end{array}$ \\
\hline
\end{tabular}

commission merchant or broker) deposit money before a trade to ensure contract performance. This deposit is usually referred to as the initial margin deposit. Each trader's margin money is maintained in a separate margin account, which is adjusted daily to reflect the gain or loss in contract value that occurred that day. This process is sometimes referred to as "Marking-to-Market," because the account is adjusted to reflect its current market value based on that day's closing or settlement price. Although the margin requirements are small relative to the total value of the contract (typically less than 5 percent of contract value), traders of futures contracts are relieved of the responsibility of worrying that the trader on the other side of the contract will default on his or her financial obligations by the mark-to-market margin system and by a series of checks and balances put in place by the exchange to ensure that sufficient funds are available to cover each account's risk exposure.

\section{Futures Trading Terminology}

To trade futures contracts you must become familiar with the terminology used in the trade. Here are some terms and definitions.

\begin{tabular}{ll}
\hline Long & $\begin{array}{l}\text { A buyer of a futures contract. Someone } \\
\text { who buys a futures contract is often } \\
\text { referred to as being long that particular } \\
\text { contract. }\end{array}$ \\
\hline Short & $\begin{array}{l}\text { A seller of a futures contract. Someone who } \\
\text { sells a futures contract is often referred to } \\
\text { as being short that particular contract. }\end{array}$ \\
\hline Bull & $\begin{array}{l}\text { A person who expects a commodity's price } \\
\text { to increase. If you are bullish about wheat } \\
\text { prices you expect them to increase. }\end{array}$ \\
\hline Bear & $\begin{array}{l}\text { A person who expects a commodity's price } \\
\text { to decline. If you are bearish about wheat } \\
\text { prices you expect them to decline. }\end{array}$ \\
\hline
\end{tabular}

Market An order to buy or sell a futures contract at order the best available price. A market order is executed by the broker immediately. "Sell one July KCBT wheat, at the market" is an example of a market order.

Limit order An order to buy or sell a futures contract at a specific price, or at a price that is more favorable than the price specified. For example, "Buy one March KCBT wheat at $\$ 6.30$ limit" means buy one March KCBT wheat contract at $\$ 6.30$ or less. In this example, the order will not be executed at a price higher than $\$ 6.30$.

Stop order An order which becomes a market order if the market reaches a specified price. A stop order to buy a futures contract would be placed with the stop price set above the current futures price. Conversely, a stop order to sell a futures contract would be placed with the stop price set below the current futures price. 


\section{Using Futures Contracts in a Farm Marketing Program}

There are a number of ways futures contracts can be used in a farm marketing program. Futures contracts can be useful when marketing grain or livestock because they can be a temporary substitute for an intended transaction in the cash market that will occur at a later date. This is a working definition of hedging. For example, if you plan on selling wheat for cash at harvest, but would like to lock in the futures price ahead of harvest, you could sell a KCBT July wheat futures contract as a temporary substitute for the cash grain you plan to sell in the future. When you actually make the cash grain sale at harvest, you will no longer need the "temporary substitute," which was your sale of the wheat futures contract. Thus, as soon as you sell the cash wheat you would exit your "temporary substitute contract" by buying a KCBT July wheat futures contract. Doing so means you no longer have an open position on the futures exchange. Your actual net sale price for the wheat would be the amount you received for the cash wheat at the elevator, plus any gain or minus any loss on the futures transaction.
Futures contract prices also can be used as a source of price forecasts. A futures contract price represents today's opinion of what a commodity's value will be when the futures contract expires. If a history of the difference between a commodity's futures contract and cash prices, for a particular grade and specific location of interest (known as the basis) is available, it can be used to estimate a futures market-based cash price forecast. For example, assume that on March 15 the KCBT July wheat futures contract is trading at $\$ 6.00$ per bushel, and your local cash market price at harvest is generally $\$ 0.40$ per bushel below the KCBT July wheat futures contract price (i.e., a basis of negative $\$ 0.40$ per bushel). In this case, a futures-based local cash price forecast at harvest time would be $\$ 5.60$ / bushel. This forecast can be compared with price forecasts from other sources such as university Extension economists, market advisory services, and the U.S. Department of Agriculture when preparing budgets and making marketing decisions.

For more details on basis and how hedging works, see the following publications in this series: Selling Hedge with Futures (E-497) and Buying Hedge with Futures (E-498).

\footnotetext{
Partial funding support has been provided by the

Texas Corn Producers, Texas Farm Bureau, and

Cotton Inc.-Texas State Support Committee.

Produced by AgriLife Communications, The Texas A\&M System

Extension publications can be found on the Web at: http://AgrilifeBookstore.org.

Visit Texas AgriLife Extension Service at http://AgriLifeExtension.tamu.edu.
}

Educational programs of the Texas AgriLife Extension Service are open to all people without regard to race, color, sex, disability, religion, age, or national origin.

Issued in furtherance of Cooperative Extension Work in Agriculture and Home Economics, Acts of Congress of May 8, 1914, as amended, and June 30, 1914, in cooperation with the United States Department of Agriculture. Edward G. Smith, Director, Texas AgriLife Extension Service, The Texas A\&M System. 